\title{
INFRARED AND RAMAN SPECTRA OF MAGNESIUM AMMONIUM PHOSPHATE HEXAHYDRATE (STRUVITE) AND ITS ISOMORPHOUS ANALOGUES. X. VIBRATIONAL SPECTRA OF MAGNESIUM RUBIDIUM ARSENATE HEXAHY- DRATE AND MAGNESIUM THALLIUM ARSENATE HEXAHYDRATE
}

\author{
Viktor Stefov $^{1,2}$, Violeta Koleva ${ }^{3}$, Metodija Najdoski ${ }^{1,2}$, Adnan Cahil $^{4}$, Zuldjevat Abdija ${ }^{5}$ \\ ${ }^{1}$ Instiute of Chemistry, Faculty of Natural Sciences and Mathematics, Ss. Cyril and Methodius University, \\ Skopje, R. N. Macedonia \\ ${ }^{2}$ Research Center for Environment and Materials, Macedonian Academy of Sciences and Arts, \\ Skopje, R. N. Macedonia \\ ${ }^{3}$ Institute of General and Inorganic Chemistry, Bulgarian Academy of Sciences, 1113 Sofia, Bulgaria \\ ${ }^{4}$ Pedagogical Faculty, Ss. Cyril and Methodius University, Skopje, R. N. Macedonia \\ ${ }^{5}$ Faculty of Natural Sciences and Mathematics, University of Tetovo, Tetovo, R. N. Macedonia \\ viktorst@pmf.ukim.mk
}

\begin{abstract}
Polycrystalline samples of struvite-type $\mathrm{MgRbAsO}_{4} \cdot 6 \mathrm{H}_{2} \mathrm{O}$ and $\mathrm{MgTlAsO}_{4} \cdot 6 \mathrm{H}_{2} \mathrm{O}$ in both protiated and deuterated forms have been prepared for the first time by a precipitation method. Detailed analysis of their infrared (IR) and Raman (R) spectra recorded at room temperature (RT) and liquid nitrogen temperature (LNT) has been carried out and assignment of the vibrational bands has been proposed. The observed spectral pictures confirm the isostructurality of the two arsenate salts in agreement with the structural data. Similarly to other struvite-type and structure-related arsenate salts, the $v_{1}\left(\mathrm{AsO}_{4}\right)$ modes appear at higher frequencies than the $v_{3}\left(\mathrm{AsO}_{4}\right)$ vibrations. Low intensity and temperature sensitive bands that could be assigned as due to stretching $\mathrm{Mg}-\mathrm{O}$ vibrations and $\mathrm{v}_{4}\left(\mathrm{AsO}_{4}\right)$ modes are observed below $500 \mathrm{~cm}^{-}$ ${ }^{1}$ in the LNT IR spectra of the studied compounds, at $472 \mathrm{~cm}^{-1}$ and $445 \mathrm{~cm}^{-1}$ for the rubidium analogue and at $470 \mathrm{~cm}^{-1}$ and $440 \mathrm{~cm}^{-1}$ for the thallium analogue. In the far-infrared and Raman spectra many bands are observed between $400 \mathrm{~cm}^{-1}$ and $200 \mathrm{~cm}^{-1}$, most of which are sensitive to deuteration, suggesting that they are not pure but coupled and can be related to $v(\mathrm{Mg}-\mathrm{Ow})$ modes. On the other hand, a band around $405 \mathrm{~cm}^{-1}$ in the spectra of the protiated compounds most probably is due to $v_{2}\left(\mathrm{AsO}_{4}\right)$ mode because of its frequency position, intensity and slight sensitivity to deuteration.
\end{abstract}

Keywords: magnesium rubidium arsenate hexahydrate; magnesium thallium arsenate hexahydrate; infrared spectra; Raman spectra

\section{ИНФРАЦРВЕН И РАМАНСКИ СПЕКТАР НА МАГНЕЗИУМ-АМОНИУМ-ФОСФАТ-ХЕКСАХИДРАТ (СТРУВИТ) И НЕГОВИТЕ ИЗОМОРФНИ АНАЛОЗИ. Х. ВИБРАЦИОНАЛНИ СПЕКТРИ НА МАГНЕЗИУМ РУБИДИУМ АРСЕНАТ ХЕКСХИДРАТ И МАГНЕЗИУМ ТАЛИУМ АРСЕНАТ ХЕКСХИДРАТ}

Подготвени се за прв пат поликристални примероци од типот на струвит $\mathrm{MgRbAsO}_{4} \cdot 6 \mathrm{H}_{2} \mathrm{O}$ и $\mathrm{MgTlAsO}_{4} \cdot 6 \mathrm{H}_{2} \mathrm{O}$ во протонирани и во деутерирани форми со методот на таложење. Извршена е детална анализа на нивните инфрацрвени (IR) спектри, снимени на собна температура и на температурата на вриење на течен азот, и рамански (R) спектри снимени на собна температура и предложена е нивна асигнација. Добиените спектри ја потврдуваат изоструктурноста на двете арсенатни соли, што е во согласност со структурните податоци. Слично на другите арсенатни соли од струвитен тип и од струвитно сродни типови на структура, модовите на $v_{1}\left(\mathrm{AsO}_{4}\right)$ се појавуваат 
на повисоки фреквенции од $v_{3}\left(\mathrm{AsO}_{4}\right)$. Лентите со послаб интензитет кои се температурно осетливи, а во инфрацрвените спектри снимени на ниски температури се забележани под $500 \mathrm{~cm}^{-1}$, може да се припишат на валентни $\mathrm{Mg}-\mathrm{O}$ вибрации и на модови на $\mathrm{v}_{4}\left(\mathrm{AsO}_{4}\right), \mathrm{Ha} 472 \mathrm{~cm}^{-1}$ и $445 \mathrm{~cm}^{-1}$ за рубидиумовиот аналог и на $470 \mathrm{~cm}^{-1}$ и $440 \mathrm{~cm}^{-1}$ за талиумовиот аналог. Во спектрите снимени во далечната инфрацрвена област и во раманските спектри се забележуваат многу ленти помеѓу $400 \mathrm{~cm}^{-1}$ и $200 \mathrm{~cm}^{-1}$, од кои повеќето се чувствителни на деутерирање, што сугерира дека тие не се чисти, туку спрегнати и можат да бидат поврзани со модовите на $v(\mathrm{Mg}-\mathrm{Ow})$. Од друга страна, поради нејзината фреквенција, интензитет и мала чувствителност на деутерирање, лентата на околу $405 \mathrm{~cm}^{-1}$ во спектарот на протонираните соединенија најверојатно се должи на модовите на $\mathrm{v}_{2}\left(\mathrm{AsO}_{4}\right)$.

Клучни зборови: магнезиум рубидиум арсенат хексахидрат; магнезиум талиум арсенат хексахидрат; инфрацрвени спектри; рамански спектри

\section{INTRODUCTION}

Magnesium ammonium phosphate hexahydrate, $\mathrm{MgNH}_{4} \mathrm{PO}_{4} \cdot 6 \mathrm{H}_{2} \mathrm{O}$ (often referred to by its mineralogical name struvite) is a well-known biomineral. Its major biological importance is related to its presence in human urinary sediments and vesical and renal calculi $[1,2]$. Besides this, struvite presents a problem in sewage and wastewater treatment. Recovery of phosphorus from waste streams as struvite and recycling these nutrients into agriculture as a fertilizer appears to be a promising potential application [3-6]. More recently, Zhou et al. demonstrated that struvite-type/struviterelated phosphates are promising materials for nonlinear optical (NLO) applications [7]. For instance $\mathrm{MgCsPO}_{4} \cdot 6 \mathrm{H}_{2} \mathrm{O}$ exhibited the strongest second harmonic generation (SHG) response among the reported UV NLO phosphates related to the presence of isolated and aligned $\mathrm{PO}_{4}$ groups in the structure of the hexahydrate salt [7].

With this contribution we continue the study of the vibrational spectra of arsenate crystal hydrates with the general formula $\mathrm{M}^{\mathrm{I}} \mathrm{MgAsO}_{4} \cdot 6 \mathrm{H}_{2} \mathrm{O}$ $\left(\mathrm{M}^{\mathrm{I}}=\mathrm{NH}_{4}, \mathrm{~K}, \mathrm{Rb}, \mathrm{Tl}\right)$ having struvite-type or closely related structures which have been a subject of our research in the last fifteen years [8-13]. Here, we have focused on rubidium and thallium representatives, $\mathrm{MgRbAsO}_{4} \cdot 6 \mathrm{H}_{2} \mathrm{O}$ and $\mathrm{MgTlAsO}_{4} \cdot 6 \mathrm{H}_{2} \mathrm{O}$ that are very little known. To the best of our knowledge, besides the determination of their crystal structure [14] no other data about the title compounds were reported so far. The aim of the present paper is to report and interpret the infrared and Raman spectra of $\mathrm{MgRbAsO}_{4} \cdot 6 \mathrm{H}_{2} \mathrm{O}$ and $\mathrm{MgTlAsO}_{4} \cdot 6 \mathrm{H}_{2} \mathrm{O}$ and to give insights on the spectra-structure correlations.

The crystal structures of the title compounds have been determined from single crystal X-ray diffraction at room temperature [14]. They belong to the struvite-type family and crystallize in the orthorhombic system, space group $P m n 2_{1}$, with $Z=$
2. The crystal lattice of both isostructural compounds is built up from slightly distorted $\left[\mathrm{Mg}\left(\mathrm{OH}_{2}\right)_{6}\right]$ octahedra, $\mathrm{AsO}_{4}$ tetrahedra and $\left[\mathrm{M}^{\mathrm{I}} \mathrm{O}_{10}\right]$ polyhedra $\left(\mathrm{M}^{\mathrm{I}}, \mathrm{Mg}^{2+}\right.$ and $\mathrm{As}^{5+}$ lie on sites with $C_{\mathrm{s}}$ symmetry) which are connected by an extensive network of hydrogen bonds. In the unit cell there are four crystallographically different water molecules of crystallization, two of which have $C_{\mathrm{s}}$ symmetry, while the other two have $C_{1}$ symmetry. This results in the formation of seven different hydrogen bonds, six of them between the water molecules and the $\mathrm{O}$ atoms of the orthoarsenate groups, while the seventh one is between two water molecules, OW1 and OW2 following the notation given in ref. [14]. The former type of hydrogen bonds can be described as medium to strong ranging from 260.8 to $267.5 \mathrm{pm}$ and 261.7 to 268.1 $\mathrm{pm}$ in the $\mathrm{Rb}$ and $\mathrm{Tl}$ compound, respectively. The latter type is the weakest hydrogen bond present in the crystal lattices with a distance of $313.9 \mathrm{pm}$ in the rubidium compound, accordingly $308.2 \mathrm{pm}$ in the thallium one. It should be mentioned that the hydrogen bond distances in the titled arsenates are very similar to these in $\mathrm{MgKAsO}_{4} \cdot 6 \mathrm{H}_{2} \mathrm{O}$ determined at room temperature $[9,15]$. Herein, we report the preparation of polycrystalline powders of $\mathrm{MgRbAsO}_{4} \cdot 6 \mathrm{H}_{2} \mathrm{O}$ and $\mathrm{MgTlAsO}_{4} \cdot 6 \mathrm{H}_{2} \mathrm{O}$, their deuterated analogues and the subsequent spectroscopic analyses.

\section{EXPERIMENTAL}

In the literature there are no reports on the synthesis of polycrystalline powders of $\mathrm{MgRbAsO}_{4} \cdot 6 \mathrm{H}_{2} \mathrm{O}$ and $\mathrm{MgTlAsO}_{4} \cdot 6 \mathrm{H}_{2} \mathrm{O}$. In this regard, we have designed a precipitation procedure which is similar for the two arsenate salts. The first stage includes mixing of a solution of sodium hydrogenarsenate $\left(10 \mathrm{~cm}^{3}\right.$ with $\left.c=0.1 \mathrm{~mol} / \mathrm{dm}^{3}\right)$ with a solution of rubidium chloride or thallium nitrate (in both cases $10 \mathrm{~cm}^{3}$ with $c=0.2 \mathrm{~mol} / \mathrm{dm}^{3}$ ). Then, 
with continuous stirring, solutions of magnesium sulfate $\left(10 \mathrm{~cm}^{3}\right.$ with $\left.c=0.25 \mathrm{~mol} / \mathrm{dm}^{3}\right)$ and sodium hydroxide $\left(10 \mathrm{~cm}^{3}\right.$ with $\left.c=0.1 \mathrm{~mol} / \mathrm{dm}^{3}\right)$ were successively added. The synthesis was carried out at room temperature. It is interesting to note that in the case of $\mathrm{MgRbAsO}_{4} \cdot 6 \mathrm{H}_{2} \mathrm{O}$ synthesis, the precipitation process started with the addition of $\mathrm{MgSO}_{4}$ solution, while for the $\mathrm{MgTlAsO}_{4} \cdot 6 \mathrm{H}_{2} \mathrm{O}$ synthesis, the precipitation occurred only after the addition of $\mathrm{NaOH}$ solution. The beakers containing the respective precipitate and mother liquor were sealed with parafilm and were left in a refrigerator at $5{ }^{\circ} \mathrm{C}$. After 5 days of aging the precipitates they were filtered and washed carefully with a small volume of water and a mixture of water/ethanol/acetone (a volume ratio of 1:3:1). The synthesized compounds were dried on the Büchner funnel in an air flow and then at room temperature for 2 hours.

The deuterated analogues were prepared in an analogous procedure as the protiated compounds using $\mathrm{H}_{2} \mathrm{O}-\mathrm{D}_{2} \mathrm{O}$ mixtures of appropriate composition instead of $\mathrm{H}_{2} \mathrm{O}$.

The infrared spectra of the protiated and deuterated forms of the studied compounds were obtained using the Perkin-Elmer System 2000 infrared interferometer in the $4000-200 \mathrm{~cm}^{-1}$ region with a resolution of $2 \mathrm{~cm}^{-1}$. Both pressed $\mathrm{KBr}$ disks and Nujol mulls at room temperature (RT) and at the boiling temperature of liquid nitrogen (LNT) were used with 32 spectra being accumulated and averaged. Significant changes were not observed in the spectra recorded in the two matrices: $\mathrm{KBr}$ and Nujol mull. LNT spectra were recorded using a low-temperature cell Graseby Specac P/N 21525 with $\mathrm{KBr}$ windows. Far infrared spectra were obtained using Nujol and polyethylene pellets.

Raman spectra were recorded at room temperature using a micro-Raman spectrometer LabRam 300 (Horiba Jobin-Yvon). This instrument was equipped with two lasers: He-Ne laser operating at $633 \mathrm{~nm}(6 \mathrm{~mW}$ power on sample) and a double frequency $\mathrm{Nd}$ :YAG laser at $532 \mathrm{~nm}(5$ $\mathrm{mW}$ power at sample). A microscope Olympus MPlanN with magnification of 50 and 100 was also used. The spectra were recorded with a resolution of $2 \mathrm{~cm}^{-1}$ and acquisition times between 10 and $40 \mathrm{~s}$, with 15-30 scans. The GRAMS ANALYST 2000 software package was used for spectra acquisition [16] and GRAMS 32 [17] for spectra management.

X-ray diffractograms of the powder samples of the investigated compounds were recorded and analyzed to confirm the identity of the synthesized products. A Rigaku Ultima IV powder X-ray diffractometer $\left(\mathrm{CuK}_{\alpha}\right.$ radiation) was used for the $\mathrm{X}$ - ray powder diffraction (XRPD) measurements. Each sample was manually dispersed over a silicon sample plate and the data were collected at room temperature on a D/tex detector in the $2 \theta$ range from 5 to $80^{\circ}$ (scan rate $2 \% \mathrm{~min}$ ). $\mathrm{CuK} \alpha$ radiation was obtained from a generator set at $40 \mathrm{kV}$ and a current of $40 \mathrm{~mA}$. The XRPD patterns (Fig. 1) are typical for the orthorhombic struvite-type arsenate compounds [9]. In addition, the experimental XRPD pattern of $\mathrm{MgRbAsO}_{4} \cdot 6 \mathrm{H}_{2} \mathrm{O}$ matches all peaks in the reference pattern (PDF-044-0453).

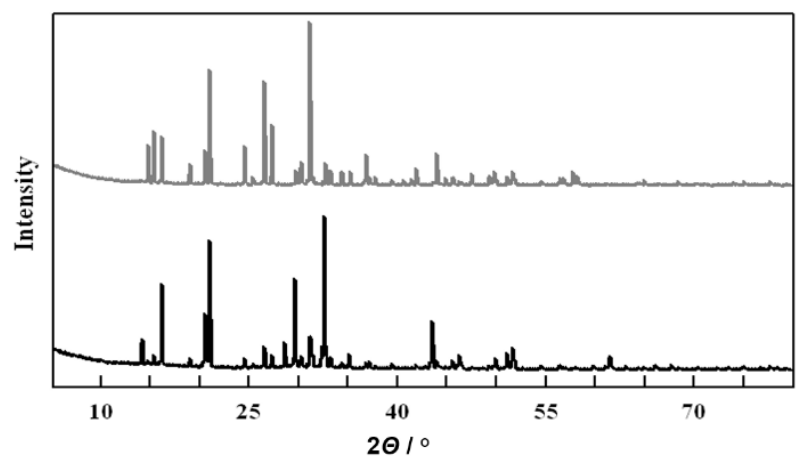

Fig. 1. Scattered intensities as a function of the diffraction angle in $\mathrm{MgRbAsO}_{4} \cdot 6 \mathrm{H}_{2} \mathrm{O}$ (lower curve)

and $\mathrm{MgTlAsO}_{4} \cdot 6 \mathrm{H}_{2} \mathrm{O}$ (upper curve), (offset spectra are presented). Intensities in the above figure are in arbitrary units (Intensity / a. u.)

\section{RESULTS AND DISCUSSION}

The infrared spectra of $\mathrm{MgRbAsO}_{4} \cdot 6 \mathrm{H}_{2} \mathrm{O}$ and $\mathrm{MgTlAsO}_{4} \cdot 6 \mathrm{H}_{2} \mathrm{O}$ recorded at RT and at boiling liquid nitrogen temperature (LNT) are given in Figures 2 and 3, and their Raman spectra recorded at RT are presented in Figure 4. The assignment of the IR and Raman bands to specific vibrational modes in the spectra of the two salts is given in Tables 1 and 2. As one would expect, the vibrational spectra of the studied two compounds recorded at RT and LNT are very similar due to their isotypism. In addition, they are very similar to the vibrational spectra of $\mathrm{MgKAsO}_{4} \cdot 6 \mathrm{H}_{2} \mathrm{O}$ previously reported by our research group [9]. It should be mentioned here that $\mathrm{MgKAsO}_{4} \cdot 6 \mathrm{H}_{2} \mathrm{O}$ undergoes a reversible phase transition at $263 \mathrm{~K}$ with a transformation from orthorhombic $\left(P m n 2_{1}\right)$ to monoclinic $\left(P 112_{1}\right)$ crystal system [15]. However, our spectroscopic data [9] revealed that this polymorphous transition does not significantly affect the appearance of the LNT IR spectra of the potassium analogue, which are still very much alike the ones obtained for $\mathrm{MgRbAsO}_{4} \cdot 6 \mathrm{H}_{2} \mathrm{O}$ and $\mathrm{Mg}$ $\mathrm{TlAsO}_{4} \cdot 6 \mathrm{H}_{2} \mathrm{O}$. The identical conclusion has been deduced for the spectra of the other related com- 
pounds with formula $\mathrm{M}^{\mathrm{I}} \mathrm{M}^{\mathrm{II}} \mathrm{XO}_{4} \cdot 6 \mathrm{H}_{2} \mathrm{O}\left(\mathrm{M}^{\mathrm{I}}=\mathrm{NH}_{4}\right.$, $\mathrm{K}, \mathrm{Rb}, \mathrm{Cs}, \mathrm{Tl} ; \mathrm{M}^{\mathrm{II}}=\mathrm{Mg}, \mathrm{Co}, \mathrm{Ni} ; \mathrm{X}=\mathrm{P}, \mathrm{As}$ ) no matter if they crystallize in the orthorhombic, hexagonal, cubic or monoclinic system and/or correspondingly they have four, two or one crystallographically different water molecules of crystallization in their structure $[8,9,13,18-25]$. The only difference that is evident in these spectra is in the region of the $\mathrm{HOH}$ librations and is dependent on the number of the crystallographically different water molecules of crystallization that exist in the structure and the type of the anion (phosphate or arsenate).

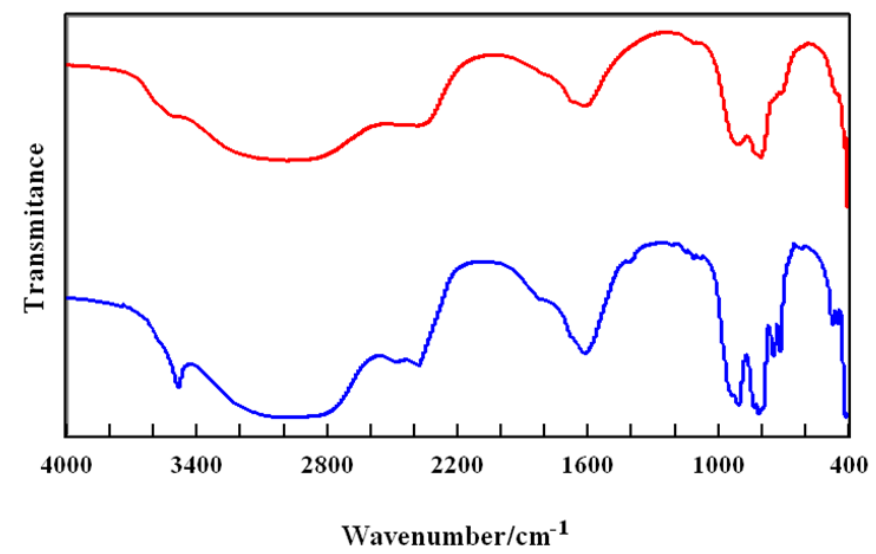

Fig. 2. Infrared spectra of $\mathrm{MgRbAsO}_{4} \cdot 6 \mathrm{H}_{2} \mathrm{O}$ recorded at $\mathrm{LNT}$ (lower curve) and at RT (upper curve) (offset spectra are presented).

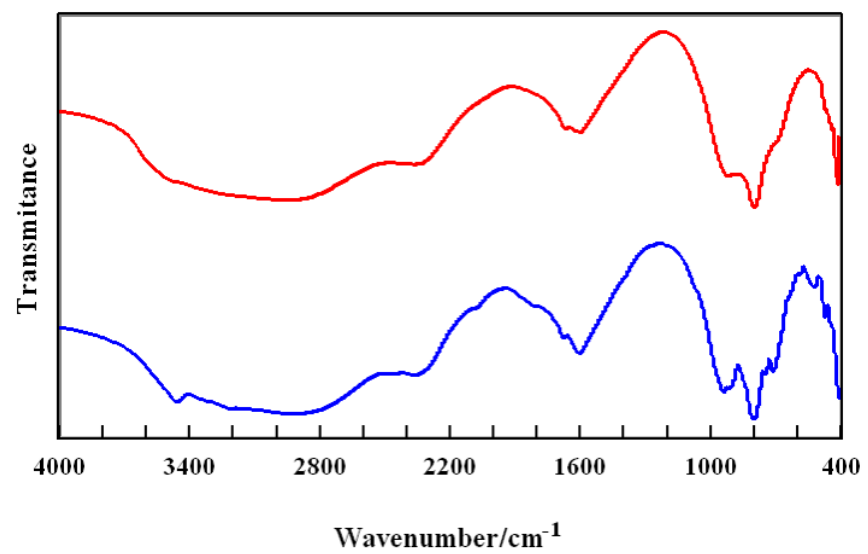

Fig. 3. Infrared spectra of $\mathrm{MgTlAsO}_{4} \cdot 6 \mathrm{H}_{2} \mathrm{O}$ recorded at LNT (lower curve) and at RT (upper curve) (offset spectra are presented).

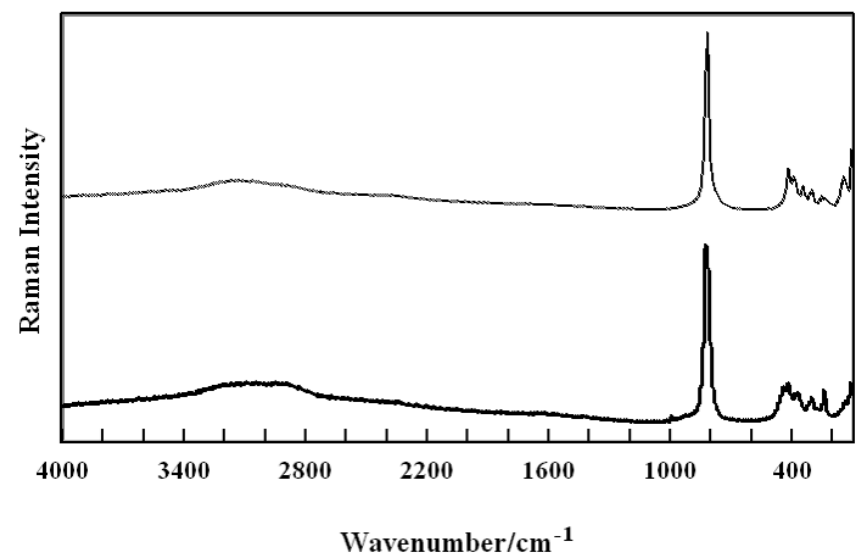

Fig. 4. Raman spectra of $\mathrm{MgRbAsO}_{4} \cdot 6 \mathrm{H}_{2} \mathrm{O}$ (lower curve) and $\mathrm{MgTlAsO}_{4} \cdot 6 \mathrm{H}_{2} \mathrm{O}$ (upper curve) recorded at RT (offset spectra are presented). 


\section{T a ble 1}

Assignments of the vibrational bands in the IR and Raman spectra of $\mathrm{MgRbAs} \mathrm{O}_{4} \cdot 6 \mathrm{H}_{2} \mathrm{O}$ with their estimated intensities ${ }^{a}$

\begin{tabular}{|c|c|c|c|c|c|c|}
\hline \multicolumn{3}{|l|}{$0 \% \mathrm{D}$} & \multicolumn{3}{|c|}{ about $95 \% \mathrm{D}$} & \multirow[t]{2}{*}{ Assignments } \\
\hline IR spectra & & Raman spectra & IR spectra & & Raman spectra & \\
\hline RT & LNT & RT & RT & LNT & RT & \\
\hline \multirow[t]{2}{*}{$\begin{array}{l}3800-2100 \\
\text { vs, br }\end{array}$} & $\begin{array}{l}3800-2000 \\
\text { vs, br }\end{array}$ & $\begin{array}{l}3500-2200 \\
\text { w, br }\end{array}$ & & & & $\begin{array}{l}\text { Related to } \\
v(\mathrm{HOH})\end{array}$ \\
\hline & & & $\begin{array}{l}2700-1550 \\
\text { vs, br }\end{array}$ & $\begin{array}{l}2700-1550 \\
\text { vs, br }\end{array}$ & $\begin{array}{l}2600-2000 \\
w, \text { br }\end{array}$ & $\begin{array}{l}\text { Related to } \\
v(\text { DOD })\end{array}$ \\
\hline \multirow[t]{3}{*}{$\begin{array}{l}2000-1350 \\
\mathrm{~m}, \mathrm{br}\end{array}$} & $\begin{array}{l}2000-1350 \\
\mathrm{~m}, \mathrm{br}\end{array}$ & $\begin{array}{l}1900-1350 \\
\text { vw, br }\end{array}$ & & & & $\begin{array}{l}\text { Related to } \\
\delta(\mathrm{HOH})\end{array}$ \\
\hline & & & $\begin{array}{l}1350-1000 \\
\mathrm{~m}, \mathrm{br}\end{array}$ & $\begin{array}{l}1350-1000 \\
\mathrm{~m}, \mathrm{br}\end{array}$ & $\begin{array}{l}\text { Around } 1200 \\
\mathrm{vw}\end{array}$ & $\begin{array}{l}\text { Related to } \\
\delta(\mathrm{DOD})\end{array}$ \\
\hline & $930 \mathrm{~s}$ & & & & & $\mathrm{~L}\left(\mathrm{H}_{2} \mathrm{O}\right)$ \\
\hline $900 \mathrm{~s}$ & $905 \mathrm{~s}$ & & & & & $\mathrm{~L}\left(\mathrm{H}_{2} \mathrm{O}\right)$ \\
\hline $828 \mathrm{~s}$ & $830 \mathrm{~s}$ & & & & & $\mathrm{~L}\left(\mathrm{H}_{2} \mathrm{O}\right)$ \\
\hline $735 \mathrm{w}$ & $740 \mathrm{~m}$ & & & & & $\mathrm{~L}\left(\mathrm{H}_{2} \mathrm{O}\right)$ \\
\hline \multirow[t]{2}{*}{$704 \mathrm{w}$} & $710 \mathrm{~m}$ & & & & & $\mathrm{~L}\left(\mathrm{H}_{2} \mathrm{O}\right)$ \\
\hline & & 816 vs & & & 824 vs & $v_{1}\left(\mathrm{AsO}_{4}\right)$ \\
\hline \multirow[t]{7}{*}{810 vs } & 810 vs & & $815 \mathrm{~s}$ & $820 \mathrm{~s}$ & & $\mathrm{v}_{3}\left(\mathrm{AsO}_{4}\right)$ \\
\hline & & & & $680 \mathrm{~s}$ & & $\mathrm{~L}\left(\mathrm{D}_{2} \mathrm{O}\right)$ \\
\hline & & & & $645 \mathrm{~m}$ & & $\mathrm{~L}\left(\mathrm{D}_{2} \mathrm{O}\right)$ \\
\hline & & & & $590 \mathrm{~m}$ & & $\mathrm{~L}\left(\mathrm{D}_{2} \mathrm{O}\right)$ \\
\hline & & & & $570 \mathrm{~m}$ & & $\mathrm{~L}\left(\mathrm{D}_{2} \mathrm{O}\right)$ \\
\hline & & & & $548 \mathrm{~m}$ & & $\mathrm{~L}\left(\mathrm{D}_{2} \mathrm{O}\right)$ \\
\hline & & & & $519 \mathrm{~m}$ & & $\mathrm{~L}\left(\mathrm{D}_{2} \mathrm{O}\right)$ \\
\hline $470 \mathrm{vw}$ & $472 \mathrm{w}$ & & $460 \mathrm{vw}$ & $465 \mathrm{w}$ & & $\begin{array}{l}\text { related to: } \\
v(\mathrm{Mg}-\mathrm{O})\end{array}$ \\
\hline \multirow[t]{6}{*}{$442 \mathrm{vw}$} & $445 \mathrm{w}$ & $436 \mathrm{w}$ & $436 \mathrm{vw}$ & $435 \mathrm{w}$ & & $\begin{array}{l}\text { and/or } \\
v_{4}\left(\mathrm{AsO}_{4}\right)\end{array}$ \\
\hline & $405 \mathrm{~m}$ & $413 \mathrm{w}$ & & $401 \mathrm{~m}$ & $403 \mathrm{vw}$ & $\mathrm{v}_{2}\left(\mathrm{AsO}_{4}\right)$ \\
\hline & $362 \mathrm{vw}$ & $370 \mathrm{vw}$ & & $355 \mathrm{vw}$ & $370 \mathrm{vw}$ & $v(\mathrm{Mg}-\mathrm{O})$ \\
\hline & $303 \mathrm{~m}$ & $298 \mathrm{vw}$ & & $293 \mathrm{~m}$ & $288 \mathrm{vw}$ & $v(\mathrm{Mg}-\mathrm{O})$ \\
\hline & $230 \mathrm{~m}$ & $234 \mathrm{vw}$ & & $225 \mathrm{~m}$ & $223 \mathrm{vW}$ & $v(\mathrm{Mg}-\mathrm{O})$ \\
\hline & $210 \mathrm{~m}$ & & & $205 \mathrm{~m}$ & & $v(\mathrm{Mg}-\mathrm{O})$ \\
\hline
\end{tabular}

a) Estimated intensities: s: strong, m: medium, w: weak, v: very, sh: shoulder, br: broad, v: stretching, $\delta$ : bending, L: libration 
Table 2

Assignments of the vibrational bands in the IR and Raman spectra of $\mathrm{MgTlAs}_{4} \cdot 6 \mathrm{H}_{2} \mathrm{O}$ with their estimated intensities ${ }^{a)}$

\begin{tabular}{|c|c|c|c|c|c|c|}
\hline \multirow{2}{*}{$\begin{array}{l}0 \% \mathrm{D} \\
\text { IR spectra }\end{array}$} & & & \multicolumn{3}{|c|}{ About $95 \% \mathrm{D}$} & \multirow[t]{2}{*}{ Assignments } \\
\hline & & Raman spectra & IR spectra & & Raman spectra & \\
\hline RT & LNT & RT & RT & LNT & RT & \\
\hline \multirow[t]{2}{*}{ vs, br } & $\begin{array}{l}3800-2000 \\
\text { vs, br }\end{array}$ & $\begin{array}{l}3500-2200 \\
w, \text { br }\end{array}$ & & & & $\begin{array}{l}\text { Related to } \\
v(\mathrm{HOH})\end{array}$ \\
\hline & & & $\begin{array}{l}2700-1550 \\
\text { vs, br }\end{array}$ & $\begin{array}{l}2700-1550 \\
\text { vs, br }\end{array}$ & $\begin{array}{l}2600-2000 \\
w, \text { br }\end{array}$ & $\begin{array}{l}\text { Related to } \\
v(\text { DOD })\end{array}$ \\
\hline \multirow[t]{3}{*}{$\mathrm{m}, \mathrm{br}$} & $\begin{array}{l}2000-1350 \\
\mathrm{~m}, \mathrm{br}\end{array}$ & $\begin{array}{l}1900-1350 \\
\text { vw, br }\end{array}$ & & & & $\begin{array}{l}\text { related to } \\
\delta(\mathrm{HOH})\end{array}$ \\
\hline & & & $\begin{array}{l}1350-1000 \\
\mathrm{~m}, \text { br }\end{array}$ & $\begin{array}{l}1350-1000 \\
\mathrm{~m}, \mathrm{br}\end{array}$ & $\begin{array}{l}\text { Around } 1200 \\
\text { vw }\end{array}$ & $\begin{array}{l}\text { Related to } \\
\delta(\mathrm{DOD})\end{array}$ \\
\hline & $930 \mathrm{~s}$ & & & & & $\mathrm{~L}\left(\mathrm{H}_{2} \mathrm{O}\right)$ \\
\hline \multirow[t]{2}{*}{$900 \mathrm{~s}$} & $905 \mathrm{~s}$ & & & & & $\mathrm{~L}\left(\mathrm{H}_{2} \mathrm{O}\right)$ \\
\hline & $830 \mathrm{~m}, \mathrm{sh}$ & & & & & $\mathrm{L}\left(\mathrm{H}_{2} \mathrm{O}\right)$ \\
\hline $735 \mathrm{w}$ & $740 \mathrm{~m}$ & & & & & $\mathrm{~L}\left(\mathrm{H}_{2} \mathrm{O}\right)$ \\
\hline \multirow[t]{2}{*}{$690 \mathrm{w}$} & $700 \mathrm{~m}$ & & & & & $\mathrm{~L}\left(\mathrm{H}_{2} \mathrm{O}\right)$ \\
\hline & & 814 vs & & & $821 \mathrm{vs}$ & $v_{1}\left(\mathrm{AsO}_{4}\right)$ \\
\hline \multirow[t]{6}{*}{$795 \mathrm{vs}$} & 795 vs & & $805 \mathrm{~s}$ & $805 \mathrm{~s}$ & & $v_{3}\left(\mathrm{AsO}_{4}\right)$ \\
\hline & & & & $675 \mathrm{~s}$ & & $\mathrm{~L}\left(\mathrm{D}_{2} \mathrm{O}\right)$ \\
\hline & & & & $645 \mathrm{~m}$ & & $\mathrm{~L}\left(\mathrm{D}_{2} \mathrm{O}\right)$ \\
\hline & & & & $580 \mathrm{~m}$ & & $\mathrm{~L}\left(\mathrm{D}_{2} \mathrm{O}\right)$ \\
\hline & & & & $555 \mathrm{~m}$ & & $\mathrm{~L}\left(\mathrm{D}_{2} \mathrm{O}\right)$ \\
\hline & & & & $510 \mathrm{~m}$ & & $\mathrm{~L}\left(\mathrm{D}_{2} \mathrm{O}\right)$ \\
\hline $470 \mathrm{vw}$ & $470 \mathrm{w}$ & & $460 \mathrm{vw}$ & $458 \mathrm{w}$ & & $\begin{array}{l}\text { Related to: } \\
v(\mathrm{Mg}-\mathrm{O})\end{array}$ \\
\hline \multirow[t]{6}{*}{$440 \mathrm{vw}$} & $440 \mathrm{w}$ & $430 \mathrm{w}$ & $435 \mathrm{vw}$ & $435 \mathrm{w}$ & & $\begin{array}{l}\text { and/or } \\
\mathrm{v}_{4}\left(\mathrm{AsO}_{4}\right)\end{array}$ \\
\hline & $405 \mathrm{~m}$ & $413 \mathrm{w}$ & & $402 \mathrm{~m}$ & $403 \mathrm{vw}$ & $\mathrm{v}_{2}\left(\mathrm{AsO}_{4}\right)$ \\
\hline & $383 \mathrm{~m}$ & $380 \mathrm{vw}$ & & $375 \mathrm{~m}$ & $373 \mathrm{vw}$ & $v(\mathrm{Mg}-\mathrm{O})$ \\
\hline & $304 \mathrm{~m}$ & $335 \mathrm{vw}$ & & $293 \mathrm{~m}$ & $330 \mathrm{vw}$ & $v(\mathrm{Mg}-\mathrm{O})$ \\
\hline & $285 \mathrm{w}$ & $296 \mathrm{vw}$ & & $273 w$ & $283 \mathrm{vw}$ & $v(\mathrm{Mg}-\mathrm{O})$ \\
\hline & $223 \mathrm{~m}$ & $248 \mathrm{vw}$ & & $219 \mathrm{~m}$ & $240 \mathrm{vw}$ & $v(\mathrm{Mg}-\mathrm{O})$ \\
\hline
\end{tabular}

a) Estimated intensities: s: strong, m: medium, w: weak, v: very, sh: shoulder, br: broad, v: stretching, $\delta$ : bending, L: libration

\subsection{Internal vibrations of water molecules}

The available data is in agreement with the existence of four types of crystallographically different water molecules of crystallization in the crystal structures of the studied compounds [14].

The group theory considerations, previously reported for the orthorhombic struvite-type compounds $[8,9,18-22,24]$, imply that due to the existence of a static field three IR and three Raman active bands are expected from each type of water molecule. Furthermore, taking into account the correlation field, the number of the bands could be significantly increased.

A closer look in the stretching $\mathrm{HOH}$ region in the RT and LNT spectra of the titled compounds
(Figs. 2-4) and the spectra of the compounds with formula $\mathrm{M}^{\mathrm{I}} \mathrm{M}^{\mathrm{II}} \mathrm{XO}_{4} \cdot 6 \mathrm{H}_{2} \mathrm{O}\left(\mathrm{M}^{\mathrm{I}}=\mathrm{NH}_{4}, \mathrm{~K}, \mathrm{Rb}, \mathrm{Cs}\right.$, $\left.\mathrm{Tl} ; \mathrm{M}^{\mathrm{II}}=\mathrm{Mg}, \mathrm{Co}, \mathrm{Ni} ; \mathrm{X}=\mathrm{P}, \mathrm{As}\right)$, no matter the crystal system $[8,9,13,18-25]$, in the region between $3800 \mathrm{~cm}^{-1}$ and $2200 \mathrm{~cm}^{-1}$ in the IR spectra and between $3500 \mathrm{~cm}^{-1}$ and $2200 \mathrm{~cm}^{-1}$ in the Raman spectra, one wide and asymmetric band with many shoulders is observed that is more intensive in the IR spectra and is sensitive to deuteration (Figs. 2-4). This is clearly a result of overlapping of several bands resulting in such a wide and asymmetric band. All of these bands are due to stretching vibrations of water molecules and/or are related to them. The position and the width of this asymmetric band infer that medium to strong hydrogen bonds exist in 
the structure of the studied compounds which is consistent with the structural data. On the other hand, the sharp band with lower intensity at higher frequency (in general higher than $3450 \mathrm{~cm}^{-1}$ ), suggests the existence of weaker hydrogen bonds in the systems, which is again in accordance with the structural data. Deuteration also affects these bands shifting them to lower frequencies (Fig. 5).

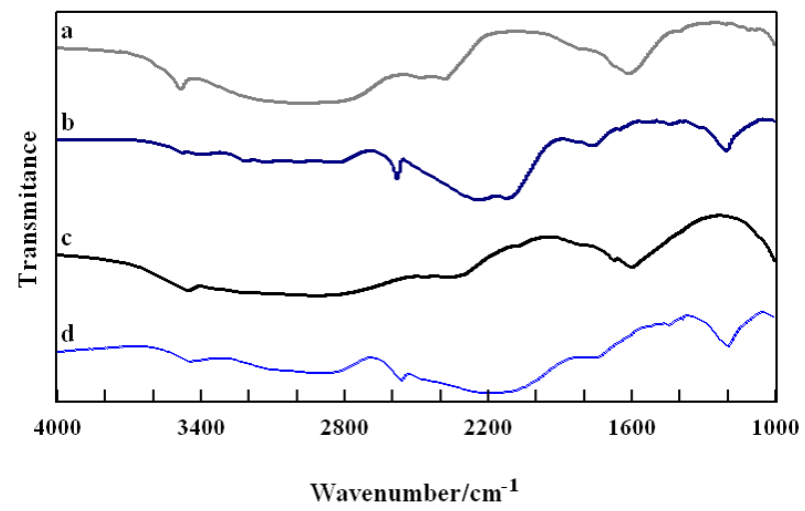

Fig. 5. Infrared spectra recorded at $\mathrm{LNT}$ of: $\mathrm{MgRbAsO}_{4} \cdot 6 \mathrm{H}_{2} \mathrm{O}$ (a) and its almost completely deuterated analogue (b); $\mathrm{MgTlAsO}_{4} \cdot 6 \mathrm{H}_{2} \mathrm{O}$ (c) and its almost completely deuterated analogue (d); in the region of the $\mathrm{OH} / \mathrm{OD}$ stretching vibrations and $\mathrm{HOH} / \mathrm{DOD}$ bending vibrations (offset spectra are presented.)

The spectral picture of both investigated compounds is similar in the bending $\mathrm{HOH}$ region from around $2000 \mathrm{~cm}^{-1}$ to $1350 \mathrm{~cm}^{-1}$ (Figs. 2-5). Namely, in the LNT IR spectra of $\mathrm{MgRbAsO}_{4} \cdot 6 \mathrm{H}_{2} \mathrm{O}$ and $\mathrm{MgTlAsO}_{4} \cdot 6 \mathrm{H}_{2} \mathrm{O}$ there are submaxima with lower intensities appearing at around $1810 \mathrm{~cm}^{-1}, 1670 \mathrm{~cm}^{-1}$, as well as more intensive ones at around $1600 \mathrm{~cm}^{-1}$. The bands in this region are temperature sensitive i.e. the frequency of some of them increases and of some of them decreases with lowering temperature. It should be mentioned here that in the spectra of the cubic form of $\mathrm{MgCsAsO}_{4} \cdot 6 \mathrm{H}_{2} \mathrm{O}$ [13], the lowest frequency band in this region is observed at 1520 $\mathrm{cm}^{-1}$ which is a frequency lower than the one of the bending $\mathrm{HOH}$ vibration of gaseous water (1595 $\left.\mathrm{cm}^{-1}\right)$. Such bands have been observed in the spectra of the compounds with formula $\mathrm{M}^{\mathrm{I}} \mathrm{M}^{\mathrm{II}} \mathrm{XO}_{4} \cdot 6 \mathrm{H}_{2} \mathrm{O}\left(\mathrm{M}^{\mathrm{I}}=\mathrm{NH}_{4}, \mathrm{~K}, \mathrm{Rb}, \mathrm{Cs}, \mathrm{Tl} ; \mathrm{M}^{\mathrm{II}}=\right.$ $\mathrm{Mg}, \mathrm{Co}, \mathrm{Ni} ; \mathrm{X}=\mathrm{P}, \mathrm{As}$ ) and they can be explained as due to second order transitions, Fermi type of resonance interactions (resonance interactions of overtones of lower frequency modes with $\delta(\mathrm{HOH})$ vibrations) or to coupling with low frequency lattice modes [8-13]. All these mechanisms are generally physically feasible and none of them (or their combination) should be neglected.

\subsection{External vibrations of the water molecules}

Comparison of the RT and LNT infrared spectra (Figs. 2 and 3) implies temperature sensitivity of all bands below $1000 \mathrm{~cm}^{-1}$. After a systematic analysis of the RT and LNT spectra of the protiated and partially deuterated forms of $\mathrm{MgRbAsO}_{4} \cdot 6 \mathrm{H}_{2} \mathrm{O}$ (Figs. 2 and 6), as well as $\mathrm{H}_{2} \mathrm{O} / \mathrm{D}_{2} \mathrm{O}$ isotopic shifts of the bands, we assigned the bands at around $930 \mathrm{~cm}^{-1}, 900 \mathrm{~cm}^{-1}$, and some of the bands around $830 \mathrm{~cm}^{-1}, 740 \mathrm{~cm}^{-1}$ and 710 $\mathrm{cm}^{-1}$ to the librational modes (Table 1). In the spectra of the thallium analogue (Figs. 3 and 7), the corresponding bands are assigned at around 930 $\mathrm{cm}^{-1}, 900 \mathrm{~cm}^{-1}$, and some of the bands around $830 \mathrm{~cm}^{-1}, 740$ and $700 \mathrm{~cm}^{-1}$ (Table 2). Namely, all these bands in the spectra of both compounds are quite temperature sensitive (Figs. 2 and 3) and their intensities systematically decrease in the spectra of the deuterated analogues, when increasing the deuterium content (Figs. 6 and 7). Simultaneously, new bands appear which, in the spectrum of the rubidium analogue with highest deuterium content, have wavenumbers of $680 \mathrm{~cm}^{-1}, 645 \mathrm{~cm}^{-1}$, around $590 \mathrm{~cm}^{-1}$ and $570 \mathrm{~cm}^{-1}, 548 \mathrm{~cm}^{-1}$ and 519 $\mathrm{cm}^{-1}$, and in the spectrum of the thallium analogue the corresponding wavenumbers are $675 \mathrm{~cm}^{-1}, 645$ $\mathrm{cm}^{-1}$, around $580 \mathrm{~cm}^{-1}, 555 \mathrm{~cm}^{-1}$ and $510 \mathrm{~cm}^{-1}$, values that are expected if these new bands are indeed due to $\mathrm{D}_{2} \mathrm{O}$ librations.

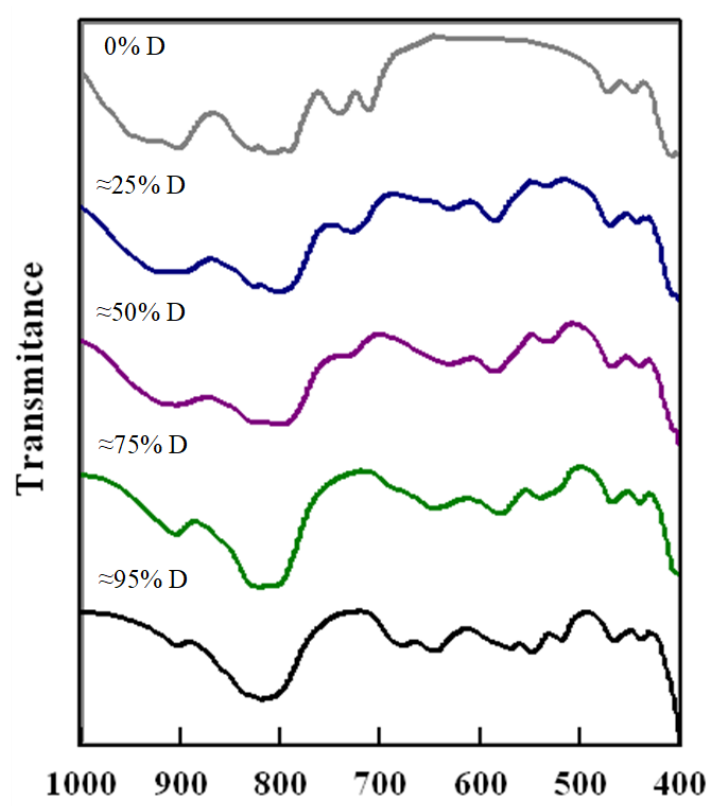

\section{Wavenumber $/ \mathrm{cm}^{-1}$}

Fig. 6. Infrared spectra of partially and nearly fully deuterated analogues of $\mathrm{MgRbAsO}_{4} \cdot 6 \mathrm{H}_{2} \mathrm{O}$ recorded at LNT in the region of the $\mathrm{HOH}$ external and $\mathrm{AsO}_{4}$ internal vibrations (the content of deuterium increases from top to bottom, offset spectra are presented.) 


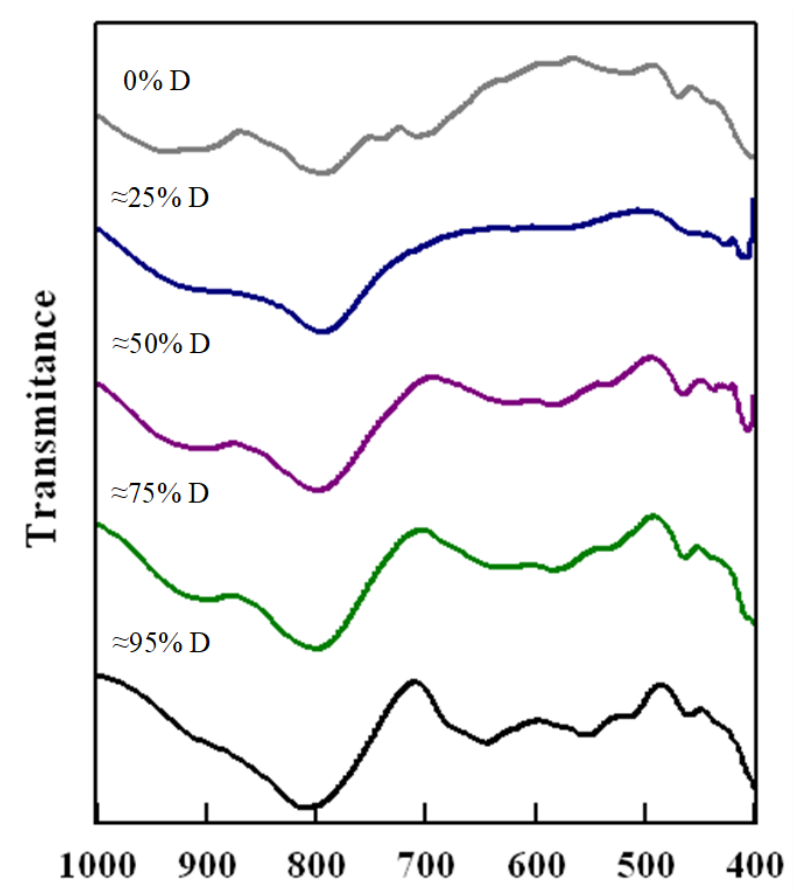

\section{Wavenumber $/ \mathrm{cm}^{-1}$}

Fig. 7. Infrared spectra of partially and nearly fully deuterated analogues of $\mathrm{MgTlAsO}_{4} \cdot 6 \mathrm{H}_{2} \mathrm{O}$ recorded at LNT in the region of the $\mathrm{HOH}$ external and $\mathrm{AsO}_{4}$ internal vibrations (The content of deuterium increases from top to bottom, offset spectra are presented.)

Furthermore, the high frequencies of some $\mathrm{H}_{2} \mathrm{O}$ librational bands arise from the considerable strength of the hydrogen bonds formed by the water molecules [26], which is in accordance with the structural data showing existence of water molecules involved in formation of strong hydrogen bonds [14].

In the Raman spectra of $\mathrm{MgRbPO}_{4} \cdot 6 \mathrm{H}_{2} \mathrm{O}$ and $\mathrm{MgTIPO}_{4} \cdot 6 \mathrm{H}_{2} \mathrm{O}$ recorded at RT, no bands with significant intensity are observed in the region from around $900 \mathrm{~cm}^{-1}$ to $500 \mathrm{~cm}^{-1}$ that could be attributed to librations of the water molecules (Fig. 4).

\subsection{Vibrations of the arsenate ions}

Free phosphate ions have tetrahedral symmetry i.e. $T_{\mathrm{d}}$ symmetry. Four normal vibrational modes $v_{1}, v_{2}, v_{3}$ and $v_{4}$, exist for this type of groups, vibrations assigned as $v_{1}$ and $v_{3}$ being stretching, and $v_{2}$ and $v_{4}$ bending vibrations. All four modes are Raman active, and $v_{3}$ (antisymmetric stretching vibration) and $v_{4}$ (antisymmetric bending vibration) being IR active.

The group-theory considerations predict that the transformation of the symmetry type from $T_{\mathrm{d}}$ to
$C_{\mathrm{s}}$ gives rise to nine bands in both infrared and Raman spectra corresponding to internal vibrations of the $\mathrm{AsO}_{4}{ }^{3-}$ ion (three components of $v_{3}$ and $v_{4}$ each, two of $v_{2}$ and one of $v_{1}$ ). Moreover, due to the influence of the correlation field, a total of 15 infrared active and 18 Raman active bands would be expected.

In the region of the $v_{3}$ modes in the LNT IR spectra of the studied compounds, one very intensive and asymmetric band with several shoulders (more prominent in the spectrum of the rubidium analogue) is observed at around $800 \mathrm{~cm}^{-1}$ that is very sensitive to temperature and deuterium exchange (Figs. 2, 3, 6 and 7). It was previously discussed that some of these shoulders are due to $\mathrm{HOH}$ librations. In the IR spectrum of the analogue with the highest deuterium content this band is less asymmetric with a center at around $820 \mathrm{~cm}^{-1}$ for the rubidium compound (Fig. 6) and $805 \mathrm{~cm}^{-1}$ for the thallium analogue (Fig. 7). These bands can be with great certainty assigned to the $v_{3}\left(\mathrm{AsO}_{4}\right)$ modes, whereas the less intensive bands to the $v_{1}\left(\mathrm{AsO}_{4}\right)$ vibrations. In this region in the Raman spectra compounds one very intensive band appears at $816 \mathrm{~cm}^{-1}$ and $814 \mathrm{~cm}^{-1}$ for rubidium and thallium analogue, respectively, that is attributed to the $v_{1}\left(\mathrm{AsO}_{4}\right)$ vibrations. In the spectra of the compounds with the highest deuterium content these bands become narrower and shift to higher wavenumbers, $824 \mathrm{~cm}^{-1}$ and $821 \mathrm{~cm}^{-1}$, respectively. This finding suggests that the $v_{1}$ mode is not pure but probably coupled with a libration mode. In line with this hypothesis, as previously mentioned, the bands from the $v_{1}\left(\mathrm{AsO}_{4}\right)$ appear at higher frequencies in the spectra of the analogues with higher deuterium content compared to ones for the protiated analogues.

It should be also noted that in both studied compounds, the $v_{1}\left(\mathrm{AsO}_{4}\right)$ modes appear at higher frequencies than the $v_{3}\left(\mathrm{AsO}_{4}\right)$ vibrations. The same spectral feature has been established in the vibrational spectra of orthorhombic $\mathrm{MgNH}_{4} \mathrm{AsO}_{4} \cdot 6 \mathrm{H}_{2} \mathrm{O}$ and $\mathrm{MgKAsO}_{4} \cdot 6 \mathrm{H}_{2} \mathrm{O}[8,9]$ and the cubic form of $\mathrm{MgCsAsO}_{4} \cdot 6 \mathrm{H}_{2} \mathrm{O}$ [13], whereas for $\mathrm{Mg}_{2} \mathrm{KH}\left(\mathrm{AsO}_{4}\right) \cdot 15 \mathrm{H}_{2} \mathrm{O}$ it was found that both $v_{1}\left(\mathrm{AsO}_{4}\right)$ and $v_{3}\left(\mathrm{AsO}_{4}\right)$ modes have practically the same wavenumbers at around $830 \mathrm{~cm}^{-1}$ [11]. This finding is consistent with spectroscopic studies on different arsenate compounds (natural and synthetic) [27-31]. This spectroscopic behavior of $v_{1}$ and $v_{3}$ modes of $\mathrm{AsO}_{4}{ }^{3-}$ is opposite to the commonly observed for other $\mathrm{XO}_{4}$ tetrahedral groups where the $v_{1}$ wavenumbers are lower than the $v_{3}$ wavenumbers. 


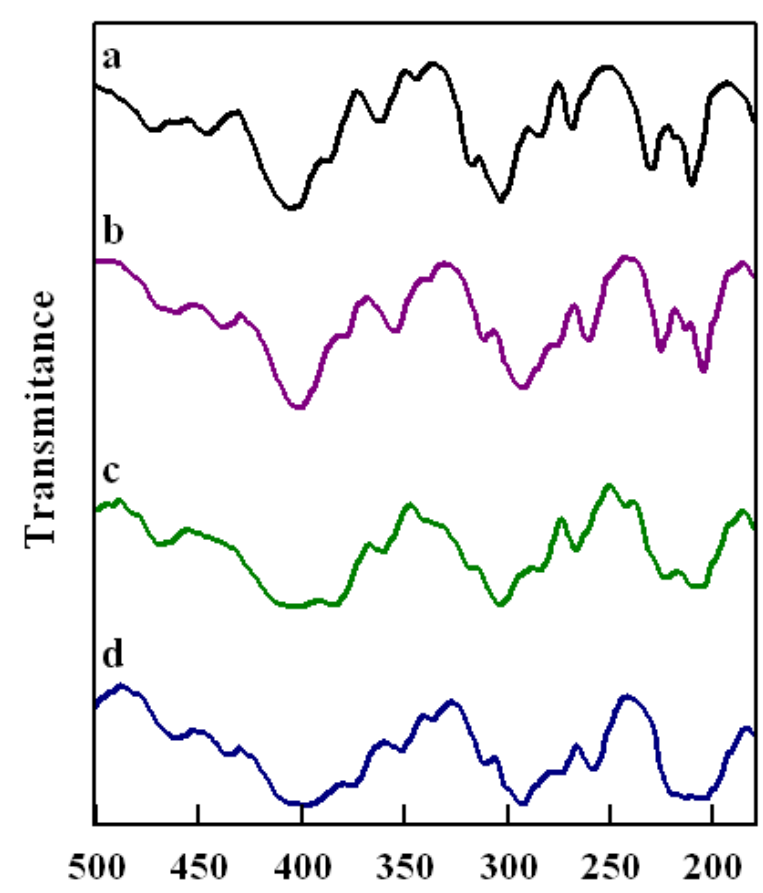

Wavenumber/ $/ \mathrm{cm}^{-1}$

Fig. 8. Far-infrared spectra recorded at LNT of: $\mathrm{MgRbAsO}_{4} \cdot 6 \mathrm{H}_{2} \mathrm{O}$ (a) and its almost completely deuterated analogue (b); $\mathrm{MgTlAsO}_{4} \cdot 6 \mathrm{H}_{2} \mathrm{O}$ (c) and its almost completely deuterated analogue (d); (Offset spectra are presented.)

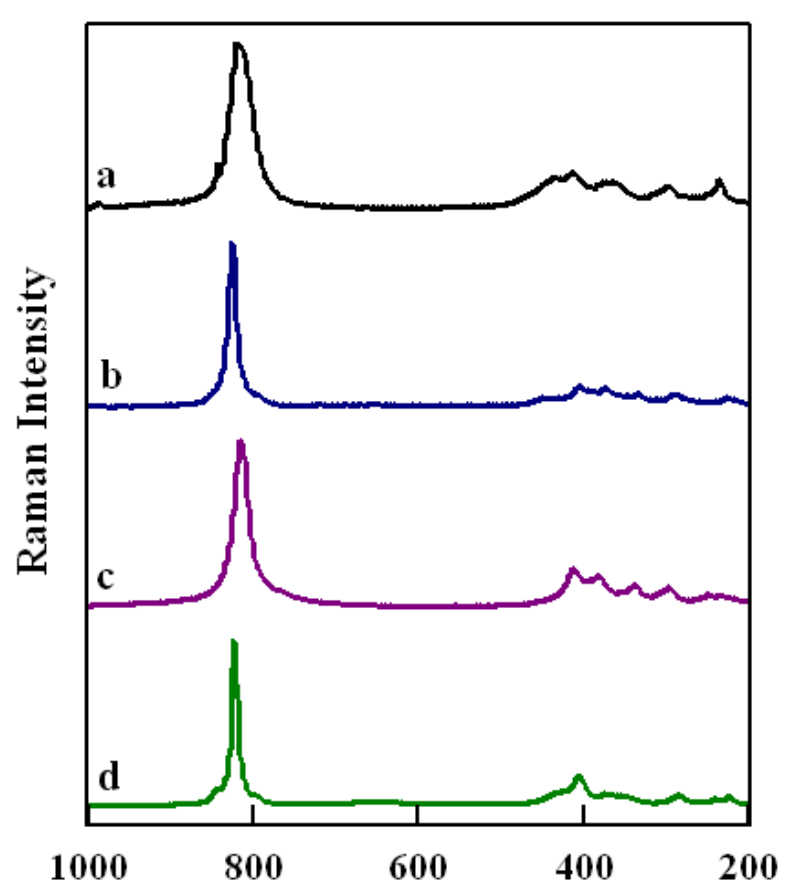

Wavenumber $/ \mathrm{cm}^{-1}$

Fig. 9. Raman spectra recorded at $\mathrm{RT}$ of: $\mathrm{MgRbAsO}_{4} \cdot 6 \mathrm{H}_{2} \mathrm{O}$ (a) and its almost completely deuterated analogue (b); $\mathrm{MgTlAsO}_{4} \cdot 6 \mathrm{H}_{2} \mathrm{O}$ (c) and its almost completely deuterated analogue (d); in the region of the $\mathrm{HOH}$ external and $\mathrm{AsO}_{4}$ internal vibrations (Offset spectra are presented.)
In the region below $500 \mathrm{~cm}^{-1}$ in the LNT IR spectra of the studied compounds, low intensity bands that are temperature sensitive are observed at $472 \mathrm{~cm}^{-1}$ and $445 \mathrm{~cm}^{-1}$ for the rubidium analogue and at $470 \mathrm{~cm}^{-1}$ and $440 \mathrm{~cm}^{-1}$ for the thallium analogue (Figs. 6 and 7). In the spectra of the partially deuterated analogues (Figs. 6 and 7) these bands are slightly shifted to lower frequencies with increasing the deuterium content. These bands could be assigned as due to stretching $\mathrm{Mg}-\mathrm{O}$ vibrations and $v_{4}\left(\mathrm{AsO}_{4}\right)$ modes. In the far-infrared (Fig. 8) and Raman spectra (Fig. 9) of both studied compounds many bands are observed in the region between $400 \mathrm{~cm}^{-1}$ and $200 \mathrm{~cm}^{-1}$ most of which being sensitive to deuterium exchange, suggesting that they are not pure but coupled and can be related to $v(\mathrm{Mg}-\mathrm{Ow})$ modes. On the other hand, the band around $405 \mathrm{~cm}^{-1}$ in the spectra of the protiated compounds most probably originates from the $v_{2}\left(\mathrm{AsO}_{4}\right)$ modes because of its frequency position, intensity and slight sensitivity to deuteration.

\section{CONCLUSION}

There is a wealth of literature data regarding the analyses of the vibrational spectra of various phosphates, but much less data for the analogous arsenate compounds. The results from this study are a contribution to the understanding of the vibrational spectra of arsenate crystal hydrates with the general formula $\mathrm{M}^{\mathrm{I}} \mathrm{MgAsO}_{4} \cdot 6 \mathrm{H}_{2} \mathrm{O}\left(\mathrm{M}^{\mathrm{I}}=\mathrm{NH}_{4}\right.$, $\mathrm{K}, \mathrm{Rb}, \mathrm{Tl}$ ) having struvite-type or closely related structures. Here, the focus was on the very little known rubidium and thallium representatives, $\mathrm{MgRbAsO}_{4} \cdot 6 \mathrm{H}_{2} \mathrm{O}$ and $\mathrm{MgTlAsO}_{4} \cdot 6 \mathrm{H}_{2} \mathrm{O}$. It has to be pointed out that in their vibrational spectra the $v_{1}\left(\mathrm{AsO}_{4}\right)$ modes appear at higher frequencies than the $v_{3}\left(\mathrm{AsO}_{4}\right)$ modes as in the other previously studied arsenate crystal hydrates. It has also been shown that $v_{1}\left(\mathrm{AsO}_{4}\right)$ and $v_{3}\left(\mathrm{AsO}_{4}\right)$ vibrations are not pure but there is probably coupling between them and/or with some water librational modes. The librational modes appear at quite high frequencies showing existence of strong hydrogen bonds involving water molecules in agreement with the structural data.

\section{REFERENCES}

[1] F. Abbona, R. Boistelle, Growth morphology and crystal habit of struvite crystals (MgNH4PO4.6H2O), J. Cryst. Growth, 46, 339-354 (1979). DOI: https://doi.org/10.1016/0022-0248(79)90082-4

[2] R. Flannigan, W. Ho Choy, B. Chew, D. Lange, Renal struvite stones-pathogenesis, microbiology, and management strategies, Nat. Rev. Urol., 11, 333-341(2014). DOI: https://doi.org/10.1038/nrurol.2014.99 
[3] K. S. le Corre, E. Valsami-Jones, P. Hobbs, B. Jefferson, S.A. Parsons, Struvite crystallisation and recovery using a stainless steel structure as a seed material, Water Res., 41, 2449-2456 (2007).

DOI: https://doi.org/10.1016/j.watres.2007.03.002

[4] K. S. le Corre, E. Valsami-Jones, P. Hobbs, B. Jefferson, S. A. Parsons, Phosphorus recovery from wastewater by struvite crystallization: A review, Crit. Rev. Environ. Sci. Technol., 39, 433-477 (2009).

DOI: https://doi.org/10.1080/10643380701640573

[5] Md. M. Rahman, M. Amran, Md. Salleh, A. Ahsan, M. M. Hossain, C. SixRa, Production of slow release crystal fertilizer from wastewaters through struvite crystallization - A review, Arab. J. Chem., 7, 139-155 (2014). DOI: https://doi.org/10.1016/j.arabjc.2013.10.007

[6] B. Tansel, G. Lunn, O. Monje, Struvite formation and decomposition characteristics for ammonia and phosphorus recovery: A review of magnesium-ammonia-phosphate interactions, Chemosphere, 194, 504-514 (2018). DOI: https://doi.org/10.1016/j.chemosphere.2017.12.0

[7] Y. Zhou, L. Cao, C. Lin, M. Luo, T. Yan, N. Ye, W. Cheng, J. Mater. Chem. C, 4, 9219-9226 (2016). DOI: https://doi.org/10.1039/C6TC03295H

[8] V. Stefov, B. Šoptrajanov, M. Najdoski, B. Engelen, H. D. Lutz, Infrared and Raman spectra of magnesium ammonium phosphate hexahydrate (struvite) and its isomorphous analogues. V. Spectra of protiated and partially deuterated magnesium ammonium arsenate hexahydrate (arsenstruvite), J. Mol. Struct., 872, 87-92 (2008).

DOI: https://doi.org/10.1016/j.molstruc.2007.02.017

[9] Z. Abdija, M. Najdoski,V. Koleva, T. Runčevski, R. E. Dinnebier, B. Soptrajanov, V. Stefov, Preparation, structural, thermogravimetric and spectroscopic study of magnesium potassium arsenate hexahydrate, Z. Anorg. Allg. Chem., 640, 3177-3183 (2014).

DOI: https://doi.org/10.1002/zaac.201400265

[10] V. Koleva, V. Stefov, M. Najdoski, Characterization and thermal decomposition of $\mathrm{Mg}_{2} \mathrm{KH}\left(\mathrm{AsO}_{4}\right)_{2} \cdot 15 \mathrm{H}_{2} \mathrm{O}, J$. Therm. Anal. Calorim., 127, 1911-1919 (2017). DOI: https://doi.org/10.1007/s10973-016-5782-2

[11] V. Stefov, V. Koleva, M. Najdoski, Z. Abdija, A. Cahil, B. Šoptrajanov, Vibrational spectra of $\mathrm{Mg}_{2} \mathrm{KH}\left(\mathrm{XO}_{4}\right)_{2} \cdot 15 \mathrm{H}_{2} \mathrm{O}(\mathrm{X}=\mathrm{P}$, As) containing dimer units $\left[\mathrm{H}\left(\mathrm{XO}_{4}\right)_{2}\right]$, Spectrochim. Acta A, 183, 387-394 (2017).

DOI: https://doi.org/10.1016/j.saa.2017.04.031

[12] M. Pecovska-Gjorgjevich,V. Stefov, M. Najdoski, V. Koleva, S. Mentus, G. Petruševski, $\mathrm{Mg}_{2} \mathrm{KH}\left(\mathrm{XO}_{4}\right)_{2} \cdot 15 \mathrm{H}_{2} \mathrm{O}$ $(\mathrm{X}=\mathrm{P}$, As) containing acidic dimer units: electrochemical impedance spectroscopy, IR spectroscopy and DSC studies, J. Alloys Compd., 746, 699-709 (2018). DOI: https://doi.org/10.1016/j.jallcom.2018.02.348

[13] V. Stefov, V. Koleva, M. Najdoski, Z. Abdija, A. Cahil, Infrared and Raman spectra of the cubic form of magnesium cesium arsenate hexahydrate, Maced. J. Chem. Chem. Eng., 37, 193-201 (2018). DOI: http://dx.doi.org/10.20450/mjcce.2018.1477

[14] M. Weil, The struvite tupe compounds $\mathrm{M}\left[\mathrm{Mg}\left(\mathrm{H}_{2} \mathrm{O}\right)_{6}\right]\left(\mathrm{XO}_{4}\right)$ where $\mathrm{M}=\mathrm{Rb}$, Tl and $\mathrm{X}=\mathrm{P}$, As, Cryst. Res. Technol., 43, 1286-1291 (2008). DOI: https://doi.org/10.1002/crat.200800403
[15] M. Weil, An unprecedented structural phase transition in struvite-type compounds: dimorphism of $\mathrm{KMgAsO}_{4}\left(\mathrm{H}_{2} \mathrm{O}\right)_{6}$, Z. Naturforsh. B, 74, 9-14 (2019). DOI: https://doi.org/10.1515/znb-2018-0119

[16] GRAMS ANALYST ${ }^{\mathrm{TM}}$ for PE-2000 FT-IR, Version 3.01B Level II, Galactic Industries, 1994.

[17] GRAMS/32 Spectral Notebase, Version 4.10, Galactic Industries Corporation, 1996.

[18] V. Stefov, B. Šoptrajanov, F. Spirovski, I. Kuzmanovski, H. D. Lutz, B. Engelen, Infrared and Raman spectra of magnesium ammonium phosphate hexahydrate (struvite) and its isomorphous analogues. I. Spectra of protiated and partially deuterated magnesium potassium phosphate hexahydrate, J. Mol. Struct., 689, 1-10 (2004).

DOI: https://doi.org/10.1016/j.molstruc.2003.08.019

[19] B. Šoptrajanov, V. Stefov, H. D. Lutz, B. Engelen, Infrared and Raman spectra of magnesium ammonium phosphate hexahydrate (struvite) and its isomorphous analogues. II. The $\mathrm{O}-\mathrm{H} / \mathrm{N}-\mathrm{H}$ streching region, in: E. Faulques, D. Perry, A. Yeremenko (Eds.), NATO Science Volume: Spectroscopy of Emerging Materials, Kluwer, Dordrecht, 2004, p. 299-308.

[20] V. Stefov, B. Šoptrajanov, I. Kuzmanovski, H. D. Lutz, B. Engelen, Infrared and Raman spectra of magnesium ammonium phosphate hexahydrate (struvite) and its isomorphous analogues. III. Spectra of protiated and partially deuterated magnesium ammonium phosphate hexahydrate, J. Mol. Struct., 752, 60-67 (2005). DOI: https://doi.org/10.1016/j.molstruc.2005.05.040

[21] A. Cahil, M. Najdoski, V. Stefov, Infrared and Raman spectra of magnesium ammonium phosphate hexahydrate (struvite) and its isomorphous analogues. IV. FTIR spectra of protiated and partially deuterated nickel ammonium phosphate hexahydrate and nickel potassium phosphate hexahydrate, J. Mol. Struct., 83 4-836, 408413 (2007).

DOI: https://doi.org/10.1016/j.molstruc.2006.11.049

[22] A. Cahil, B. Šoptrajanov, M. Najdoski, H. D. Lutz, B. Engelen, V. Stefov, Infrared and Raman spectra of magnesium ammonium phosphate hexahydrate (struvite) and its isomorphous analogues. VI. FT-IR spectra of isomorphously isolated species. $\mathrm{NN}_{4}{ }^{+}$ions isolated in $\mathrm{MKPO}_{4} \cdot 6 \mathrm{H}_{2} \mathrm{O}(\mathrm{M}=\mathrm{Mg} ; \mathrm{Ni})$ and $\mathrm{PO}_{4}{ }^{3-}$ ions isolated in $\mathrm{MgNH}_{4} \mathrm{AsO}_{4} \cdot 6 \mathrm{H}_{2} \mathrm{O}$, J. Mol. Struct., 876, 255-259 (2008).

DOI: https://doi.org/10.1016/j.molstruc.2007.06.023

[23] V. Stefov, A. Cahil, B. Šoptrajanov, M. Najdoski, F. Spirovski, B. Engelen, H. D. Lutz, V. Koleva, Infrared and Raman spectra of magnesium ammonium phosphate hexahydrate (struvite) and its isomorphous analogues. VII. Spectra of protiated and partially deuterated hexagonal magnesium caesium phosphate hexahydrate, $J$. Mol. Struct., 924-926, 100-106 (2009).

DOI: https://doi.org/10.1016/j.molstruc.2008.12.009

[24] B. Šoptrajanov, A. Cahil, M. Najdoski, V. Koleva and V. Stefov, Infrared and Raman spectra of magnesium ammonium phosphate hexahydrate (struvite) and its isomorphous analogues. VIII. Spectra of protiated and partially deuterated magnesium rubidium phosphate hexahydrate and magnesium thallium phosphate hexahydrate, Acta Chim. Slov., 58, 478-484 (2011). 
[25] V. Stefov, Z. Abdija, M. Najdoski, V. Koleva, V. M. Petruševski, T. Runčevski, R. E. Dinnebier and B. Šoptrajanov, Infrared and Raman spectra of magnesium ammonium phosphate hexahydrate (struvite) and its isomorphous analogues. IX. Spectra of protiated and partially deuterated cubic magnesium caesium phosphate hexahydrate, Vib. Spectrosc., 68, 122-128 (2013). DOI: https://doi.org/10.1016/j.vibspec.2013.06.003

[26] V. P. Tayal, B. K. Srivastava, D. P. Khandewal, H. D. Bist, Librational modes of crystal water in hydrated solids, Appl. Spectrosc. Rev., 16, 43-134 (1980). DOI: https://doi.org/10.1080/05704928008081709

[27] W. Martens, R. L. Frost, J. T. Kloprogge, Raman spectroscopy of synthetic erythrite, partially dehydrated erythrite and hydrothermally synthesized dehydrated erythrite, J. Raman Spectrosc., 34, 90-95 (2003). DOI: https://doi.org/10.1002/jrs.958

[28] W. N. Martens, J. T. Kloprogge, R. L. Frost, L. Rintoul, Single-crystal Raman study of erythrite, $\mathrm{Co}_{3}\left(\mathrm{AsO}_{4}\right)_{2} \cdot 8 \mathrm{H}_{2} \mathrm{O}$, J. Raman Spectrosc., 35, 208-216 (2004).

DOI: https://doi.org/10.1002/jrs.1136
[29] T. Mihajlović, E. Libowitzky, H. Effenberger, Synthesis, crystal structure, infrared and Raman spectra of $\mathrm{Sr}_{5}\left(\mathrm{As}_{2} \mathrm{O}_{7}\right)_{2}\left(\mathrm{AsO}_{3} \mathrm{OH}\right)$, J. Solid State Chem., 177, $3963-$ 3970 (2004).

DOI: https://doi.org/10.1016/j.jssc.2004.06.036

[30] R. L. Frost, R. Scholz, An. López, Y. Xi, Raman spectroscopy of the arsenate minerals maxwellite and in comparison with tilasite, Spectrochim. Acta A, 123, 416420 (2014).

DOI: https://doi.org/10.1016/j.saa.2013.12.081

[31] P. Makreski, J. Todorov, V. Makrievski, Lj. Pejov, G. Jovanovski, Vibrational spectra of the rare-occurring complex hydrogenarsenate minerals pharmacolite, picropharmacolite, andvladimirite: Dominance of Raman over IR spectroscopy todiscriminate arsenate and hydrogen arsenate units, J Raman Spectrosc., 49, 747-763 (2018).

DOI: https://doi.org/10.1002/jrs.5324 
